\title{
The Neuroprotective Effects of Ratanasampil on Oxidative Stress-Mediated Neuronal Damage in Human Neuronal SH-SY5Y Cells
}

\author{
Aiqin Zhu, ${ }^{1}$ Zhou Wu, ${ }^{2}$ Jie Meng, ${ }^{2}$ Patrick L. McGeer, ${ }^{3}$ Yi Zhu, \\ Hiroshi Nakanishi, ${ }^{2}$ and Shizheng $W u^{1}$ \\ ${ }^{1}$ Institution of Geriatric Qinghai Provincial Hospital, Xining 810007, China \\ ${ }^{2}$ Department of Aging Science and Pharmacology, Faculty of Dental Science, Kyushu University, Fukuoka 812-8582, Japan \\ ${ }^{3}$ Kinsmen Laboratory of Neurological Research, Department of Psychiatry, The University of British Columbia, 2255 Wesbrook Mall, \\ Vancouver, BC, Canada V6T 1W5 \\ ${ }^{4}$ Hospital Infection Management Office, Hospital of Xinjiang Production and Construction Corps, Urumqi, Xinjiang 830002, China
}

Correspondence should be addressed to Aiqin Zhu; zhuaq@hotmail.com and Zhou Wu; zhouw@dent.kyushu-u.ac.jp

Received 29 December 2014; Revised 13 April 2015; Accepted 16 April 2015

Academic Editor: Vincent Pialoux

Copyright @ 2015 Aiqin Zhu et al. This is an open access article distributed under the Creative Commons Attribution License, which permits unrestricted use, distribution, and reproduction in any medium, provided the original work is properly cited.

\begin{abstract}
We previously found that Ratanasampil (RNSP), a traditional Tibetan medicine, improves the cognitive function of mild-tomoderate $\mathrm{AD}$ patients living at high altitude, as well as learning and memory in an AD mouse model (Tg2576); however, mechanism underlying the effects of RNSP is unknown. In the present study, we investigated the effects and molecular mechanisms of RNSP on oxidative stress-induced neuronal toxicity using human neuroblastoma SH-SY5Y cells. Pretreatment with RNSP significantly ameliorated the hydrogen peroxide- $\left(\mathrm{H}_{2} \mathrm{O}_{2}\right.$-) induced cytotoxicity of SH-SY5Y cells in a dose-dependent manner (up to $60 \mu \mathrm{g} / \mathrm{mL}$ ). Furthermore, RNSP significantly reduced the $\mathrm{H}_{2} \mathrm{O}_{2}$-induced upregulation of 8-oxo-2'-deoxyguanosine (8-oxo-dG, the oxidative DNA damage marker) but significantly reversed the expression of repressor element-1 silencing transcription factor (REST) from $\mathrm{H}_{2} \mathrm{O}_{2}$ associated $(100 \mu \mathrm{M})$ downregulation. Moreover, RNSP significantly attenuated the $\mathrm{H}_{2} \mathrm{O}_{2}$-induced phosphorylation of p38 mitogen-activated protein kinase (MAPK) and extracellular signal-regulated kinase 1/2 (ERK 1/2) in SH-SY5Y cells. These observations strongly suggest that RNSP may protect the oxidative stress-induced neuronal damage that occurs through the properties of various antioxidants and inhibit the activation of MAPKs. We thus provide the principle molecular mechanisms of the effects of RNSP and indicate its role in the prevention and clinical management of AD.
\end{abstract}

\section{Introduction}

By the year 2030, roughly $20 \%$ of the world's population will be over the age of 65 years [1]. As the mean life expectancy continues to increase, the cognitive impairments associated with Alzheimer's disease (AD) will be one of the major issues in aging societies around the world. Oxidative stress is a major component of the harmful cascades activated in the development of aging-related neurodegenerative disorders, including $\mathrm{AD}[2-4]$, because oxidative stress through the overproduction of reactive oxygen species (ROS) causes cell damage through the promotion of lipid peroxidation, DNA damage, and the regulation of death proteins [5]. Numerous reports have provided direct morphological and biochemical evidence indicating the connection between oxidative stress and cell death in the brain of AD patients [6-8]. Antioxidant therapy is considered to be one of the promising approaches to the prevention and clinical management of $\mathrm{AD}$ [9].

Mitogen-activated protein kinase (MAPK) cascades are sensitive to oxidative stress. The overproduction of ROS during oxidative stress plays a role as a second messenger in signal transduction cascades leading to the activation of MAPKs, because the intracellular redox state of the cells regulates the cellular signaling pathways $[10,11]$. The members of the major MAPK subfamily, c-Jun N-terminal kinase (JNK), p38 MAPK, and extracellular signal-regulated kinase 
1/2 (ERK 1/2), are known cell death factors that increase in response to oxidative stress $[12,13]$. Indeed, increased levels of phosphorylated MAPKs have been found in the postmortem examinations of the brains of AD patients [14-16].

Ratanasampil (RNSP), the Tibetan language name which translates to "seventy-taste pearl-balls," has been traditionally used for the treatment of stroke and cerebrovascular diseases. Our previous studies have found that RNSP increases learning and memory and reduces $\beta$-amyloid $(\mathrm{A} \beta)$ protein levels in mouse AD models (Tg2576) $[17,18]$. Furthermore, we have recently found that RNSP improves the cognitive functions in mild-to-moderate $\mathrm{AD}$ patients living at high altitude and decreases serum $\mathrm{A} \beta_{42}$ concentration as well as proinflammatory factors, including Tumor Necrosis Factor (TNF- $\alpha$ ) and interleukins IL- $1 \beta$ and IL-6. These findings indicate the therapeutic effects of RNSP in the prevention and clinical management of $\mathrm{AD}$ [19]. However, the mechanism underlying these effects has remained unknown.

RNSP is composed of more than seventy components, including saffron and Glycyrrhiza uralensis [20, 21]. The beneficial effects of RNSP components have been received. Previous studies have shown that saffron effectively inhibited the TNF $\alpha$-induced cell death of PC12 cells [22] and protected neurons from the neurotoxic activity of 6-hydroxydopamine hydrobromide [23], via its antioxidant properties [24-26]. More recent studies have reported that Glycyrrhiza uralensis exerts anti-inflammatory effects by inhibiting the activation of nuclear factor-kappa $\mathrm{B}(\mathrm{NF} \kappa \mathrm{B})$ as well as the NODlike receptor family, a pyrin domain containing 3 (NLRP3) inflammasome $[27,28]$. In the present study, we focused on the effects and molecular mechanisms of RNSP in hydrogen peroxide- $\left(\mathrm{H}_{2} \mathrm{O}_{2}-\right)$ induced neuronal death using cultured SH-SY5Y cells, because $\mathrm{H}_{2} \mathrm{O}_{2}$ is one of the most important ROS generated during oxidative stress $[29,30]$ and because SH-SY5Y cells are widely used for the study of neuronal cell death induced by oxidative stress $[31,32]$. Pretreatment with RNSP was found to significantly ameliorate the $\mathrm{H}_{2} \mathrm{O}_{2}$ induced cytotoxicity of SH-SY5Y cells in a dose-dependent manner (from $10 \mu \mathrm{g} / \mathrm{mL}$ to $60 \mu \mathrm{g} / \mathrm{mL}$ ). Furthermore, RNSP was found to significantly reduce the $\mathrm{H}_{2} \mathrm{O}_{2}$-upregulated expression of 8-oxo-deoxyguanosine (8-oxo-G, major product of DNA oxidation that is widely used as an oxidative DNA damage marker) but significantly reserved repressor element1 silencing transcription factor (REST) from $\mathrm{H}_{2} \mathrm{O}_{2}$-related downregulation. Moreover, RNSP significantly attenuated the $\mathrm{H}_{2} \mathrm{O}_{2}$-induced phosphorylation of p38 and ERK1/2 in SHSY5Y cells. These observations strongly suggest that RNSP may provide a protective effect against oxidative stressinduced neuronal death via its antioxidant properties and through the inhibition of MAPK activation. The findings of this study may thus provide the principle molecular mechanisms supporting the clinical usage of RNSP in the prevention and clinical management of AD.

\section{Materials and Methods}

2.1. Reagents. Ratanasampil (RNSP, Zhunzi Z63020062) was purchased from Qinghai Jinke Tibetan Medicine Pharmaceutical Co. Ltd. (Xining, China). A suitable concentration of methanol was titrated for cell culture in order to prevent interference from the methanol solvent. $\mathrm{H}_{2} \mathrm{O}_{2}(30 \%)$ was purchased from Sigma-Aldrich (St. Louis, MO, USA). Mouse monoclonal anti-8-oxo-deoxyguanosine (8-oxo-dG) was purchased from NOF Corporation (Kyoto, Japan); rabbit anti-phospho-p38, rabbit anti-p38, rabbit anti-phosphopERK1/2, rabbit anti-phospho-ERK1/2, rabbit anti-phosphopJNK $(1: 1000)$, and rabbit anti-pJNK (1:1000) were purchased from Cell Signaling Technology (Danvers, MA, USA).

2.2. SH-SY5Y Cell Culture. Cells of the SH-SY5Y human neuroblastoma cell line, which were purchased from American Type Culture Collection (Manassas, VA, USA), were cultured in DMEM/F-12 mixture supplemented with $10 \%$ fetal bovine serum (FBS, ICN Biomedicals, Eschwege, Germany), 2 mM L-glutamine, and $1 \%$ antibiotic and antimycotic solution (Sigma, St. Louis, MO, USA) in a humid atmosphere of 5\% $\mathrm{CO}_{2}$ and $95 \%$ air at $37^{\circ} \mathrm{C}$. To determine the toxicity of the reagents, the cells were treated with freshly prepared $\mathrm{H}_{2} \mathrm{O}_{2}$ (from $30 \%$ stock) at concentrations ranging from 5 to $500 \mu \mathrm{M}$ (diluted with sterile purified water), and RNSP was tested at concentrations ranging from 0.01 to $100 \mathrm{ug} / \mathrm{mL}$ (diluted with methanol or sterile purified water) for different treatment times.

2.3. Cell Survival Assay. An MTT assay was performed as described previously [33]. Based on the preliminary observations, cells in the exponential phase of growth were seeded in 96-well plates $\left(1 \times 10^{5}\right.$ cells/well $)$, allowed to adhere to plates (for $24 \mathrm{~h}$ ), and treated with various concentrations of RNSP (diluted with methanol or sterile purified water), $\mathrm{H}_{2} \mathrm{O}_{2}$ (diluted with sterile purified water), and vehicle (methanol or sterile purified water). The relative cell viability was measured using CellQuanti-MTT Cell Viability Assay Kits (Bio Assay Systems, Hayward, USA). The assay was performed according to the manufacturer's protocol. The absorbency at $570 \mathrm{~nm}$ was evaluated using a microplate reader.

2.4. Observations of Morphological Changes. The cells were seeded in 24 -well plates $\left(2 \times 10^{5}\right.$ cells/well $)$ for $24 \mathrm{~h}$ and then treated with $\mathrm{H}_{2} \mathrm{O}_{2}$ at a concentration of $100 \mu \mathrm{M}$ for $24 \mathrm{~h}$ with or without RNSP (methanol extraction) at different concentrations. The cellular morphology was observed and photographed using a bright-field microscope (Nikon, ECLIPSE Ti-S, Japan).

2.5. Detection of Mitochondrial ROS. Mitochondrial ROS were measured using MitoSOX Red (Invitrogen, USA), which is a live-cell permeant that rapidly and selectively targets mitochondria [33]. Once in the mitochondria, MitoSOX Red reagent is oxidized by superoxide and exhibits red fluorescence (with excitation at $510 \mathrm{~nm}$ and emission at $580 \mathrm{~nm}$ ). The cultured SH-SY5Y cells were seeded in 24 -well plates $(2 \times$ $10^{5}$ cells/well) and incubated with or without RNSP for $2 \mathrm{~h}$ (methanol extraction, $60 \mu \mathrm{g} / \mathrm{mL}$ ). The cells were then further exposed to $\mathrm{H}_{2} \mathrm{O}_{2}(100 \mu \mathrm{M})$ for $1 \mathrm{~h}$. After incubation in Hank's balanced salt solution (HBSS) containing $5 \mathrm{mM}$ MitoSOX Red for $10 \mathrm{~min}$ at $37^{\circ} \mathrm{C}$, the cells were washed twice with $\mathrm{PBS}$ and then mounted in a warm buffer for imaging. Images 
were collected using a $\times 20$ objective lens $(\mathrm{NA}=0.50,200 \mathrm{x}$ magnification, yielding a frame of $0.575 \mathrm{~mm}^{2}$ ). The procedure resulted in arbitrary optical density values on a scale of 0 (background staining) to 255 .

2.6. Real-Time Quantitative RT-PCR Analysis. SH-SY5Y cells were seeded in a $10 \mathrm{~cm}^{2}$ dish $\left(1 \times 10^{7} /\right.$ dish $)$, which was pretreated with RNSP (methanol extraction, $60 \mu \mathrm{g} / \mathrm{mL}$ ) for $2 \mathrm{~h}$. The cells were then treated with $\mathrm{H}_{2} \mathrm{O}_{2}(100 \mu \mathrm{M})$ for 1 or $2 \mathrm{~h}$. The mRNAs isolated from the RNSP-pretreated or nontreated cells were subjected to a real-time quantitative RT-PCR. The total RNA was extracted with a PureLink RNA micro kit (Invitrogen, Japan), which was used in accordance with the manufacturer's instructions. A total of $800 \mathrm{ng}$ of extracted RNA were reverse-transcribed to cDNA using High Capacity RNA-to-cDNA Master Mix (Applied Biosystems, Foster City, CA). Thermal cycling was conducted at $50^{\circ} \mathrm{C}$ for $2 \mathrm{~min}$ and then at $95^{\circ} \mathrm{C}$ for $10 \mathrm{~min}$, followed by 40 cycles of $95^{\circ} \mathrm{C}$ for $15 \mathrm{~s}$ and $60^{\circ} \mathrm{C}$ for $1 \mathrm{~min}$. The cDNA was amplified in duplicate using TaqMan Universal PCR Master Mix (Applied Biosystems, Foster City, CA) with an Applied Biosystems 7500/7500 Fast Real-Time PCR System. The data were evaluated using the 7500 software program (version 2.0, Applied Biosystems). The following primer sequences were used: repressor element-1 silencing transcription factor (REST): $5^{\prime}$-TGG TGG GTG CCC AAA TTG TA- $3^{\prime}$ and $5^{\prime}$ ACC TGC ATG GGA GCA GAT TC-3'. For data normalization, an endogenous control (actin) was assessed to control for the cDNA input, and the relative units were calculated using a comparative $\mathrm{Ct}$ method. All of the real-time RT-PCR experiments were repeated three times, and the results are presented as the means of the ratios \pm SEM.

2.7. Immunofluorescence Imaging. Immunofluorescenceimaging was performed as described previously [34]. Briefly, SHSY5Y cells were seeded in 24 -well plates $\left(2 \times 10^{5}\right.$ cells/well $)$ for $24 \mathrm{~h}$, then treated with $\mathrm{H}_{2} \mathrm{O}_{2}(100 \mu \mathrm{M})$ for $4 \mathrm{~h}$, with or without pretreatment with RNSP (methanol extraction, $60 \mu \mathrm{g} / \mathrm{mL}$ ) for $2 \mathrm{~h}$, and fixed with $4 \%$ paraformaldehyde. After washing the cells with PBS twice, they were incubated with mouse anti-8-oxo-dG (1:500) overnight at $4^{\circ} \mathrm{C}$ and then incubated with anti-mouse Alexa 488 (1:2000, Jackson ImmunoResearch Lab. Inc.) at $4^{\circ} \mathrm{C}$ for $2 \mathrm{~h}$. The cells were mounted in the antifading medium, VECTASHIELD, and the fluorescence images were taken using a confocal laser scanning microscope (CLSM, C2si, Nikon, Japan).

2.8. Electrophoresis and Immunoblotting. SH-SY5Y cells were cultured at a density of $1 \times 10^{7}$ cells in $10 \mathrm{~cm}^{2}$ dishes. The cytosolic samples of the cells were collected at 10 , 30 , and $60 \mathrm{~min}$ after $\mathrm{H}_{2} \mathrm{O}_{2}(100 \mu \mathrm{M})$ treatment, with or without RNSP (methanol extraction, $60 \mu \mathrm{g} / \mathrm{mL}$ ). The lysed samples were electrophoresed in $12 \%$ SDS-polyacrylamide gels, and the proteins on the SDS gels were electrophoretically transferred to nitrocellulose membranes. Following blocking, the membranes were incubated at $4^{\circ} \mathrm{C}$ overnight under gentle agitation with each primary antibody: rabbit anti-phospho-p38 (1:1000), rabbit anti-p38 (1:1000), rabbit anti-phospho-pERK1/2 (1:1000), rabbit anti-phosphoERK1/2 (1:1000), rabbit anti-phospho-pJNK (1:1000), rabbit anti-pJNK (1:1000), and rabbit anti-phospho-pERK1/2 $(1: 1000)$ antibodies. After washing, the membranes were incubated with horseradish peroxidase- (HRP-) labeled antirabbit $\left(1: 2000\right.$, GE Healthcare, UK) antibody for $2 \mathrm{~h}$ at $24^{\circ} \mathrm{C}$. The protein bands were then detected using an enhanced chemiluminescence detection system (ECK kit, Amersham Pharmacia Biotech) with an image analyzer (LAS-4000, Fuji Photo Film, Tokyo, Japan).

2.9. Statistical Analysis. The data are represented as the means \pm SEM. Statistical analyses were performed using oneway or two-way analysis of variance (ANOVA) with post hoc Tukey's test using the GraphPad Prism software package. A $p$ value of $<0.05$ was considered to indicate statistical significance (GraphPad Software Inc., San Diego, CA, USA).

\section{Results}

3.1. Effect of RNSP on Cell Viability in SH-SY5Y Cells. We first examined the effects of RNSP on the cell viability of SHSY5Y cells using an MTT assay. The mean cell viability was not significantly changed after treatment with the methanol extracts of RNSP at final concentrations between 0.3 and $60 \mu \mathrm{g} / \mathrm{mL}$ for 5 days (Figure 1(a)). However, the mean cell viability was significantly reduced after pretreatment with RNSP at a final concentration of over $100 \mu \mathrm{g} / \mathrm{mL}$ (82\% of viable cells). It is known that the concentration of $\mathrm{H}_{2} \mathrm{O}_{2}$ in healthy individuals is normally quite low, and the elevation of $\mathrm{H}_{2} \mathrm{O}_{2}$ concentration upon cerebral ischemic and reperfusion injury could act as a significant signal $[35,36]$. We next examined the toxic effect of $\mathrm{H}_{2} \mathrm{O}_{2}$ at different concentrations (5-500 $\mu \mathrm{M}$ ) in SH-SY5Y cells, because $\mathrm{H}_{2} \mathrm{O}_{2}$ has frequently been used as an oxidative stimulus to identify redox-sensitive processes. The viability of SH-SY5Y cells was decreased after exposure to $\mathrm{H}_{2} \mathrm{O}_{2}$ for $24 \mathrm{~h}$ in a dose-dependent manner. In comparison to nonexposed cells, $56.8 \%$ of the viable cells were detected at an $\mathrm{H}_{2} \mathrm{O}_{2}$ concentration of $100 \mu \mathrm{M}$, while less than $50 \%$ of the viable cells were detected at an $\mathrm{H}_{2} \mathrm{O}_{2}$ concentration of over $125 \mu \mathrm{M}$ (Figure 1(b)). We therefore used methanol extracts of RNSP at concentrations of up to $60 \mu \mathrm{g} / \mathrm{mL}$ and $\mathrm{H}_{2} \mathrm{O}_{2}$ at $100 \mu \mathrm{M}$ concentration to investigate the effects of RNSP on the $\mathrm{H}_{2} \mathrm{O}_{2}$-induced cytotoxicity of SHSY5Y cells in the subsequent experiments.

\subsection{The Effects of RNSP on $\mathrm{H}_{2} \mathrm{O}_{2}$-Induced Toxicity in $\mathrm{SH}$-SY5Y} Cells. Pretreatment with methanol extracts of RNSP for 5 days prevented $\mathrm{H}_{2} \mathrm{O}_{2}$-induced cytotoxicity in SH-SY5Y cells in a dose-dependent manner (Figure 1(c)). In comparison to the $\mathrm{H}_{2} \mathrm{O}_{2}$-treated cells, the cell viabilities were significantly restored from treatment with RNSP at a concentration of $10 \mu \mathrm{g} / \mathrm{mL}$, and $92.8 \%$ of viable cells were detected in RNSP with a concentration of $60 \mu \mathrm{g} / \mathrm{mL}$. The protective effect of RNSP was further confirmed by the microscopic evaluation of the cells. Morphological changes that were observed included the degeneration of $\mathrm{H}_{2} \mathrm{O}_{2}$-treated SHSY5Y cells, which exhibited the disappearance of the neuritis and shrinkage (Figure 1(d)). The percentage of viable cells was 


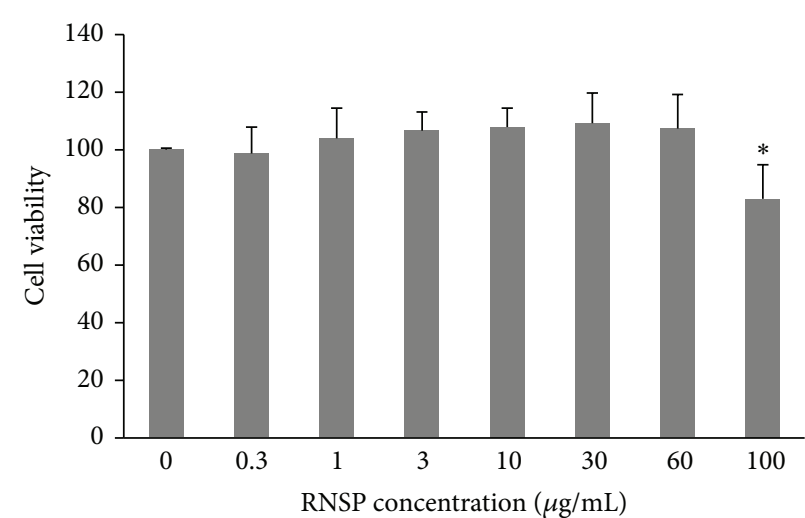

(a)

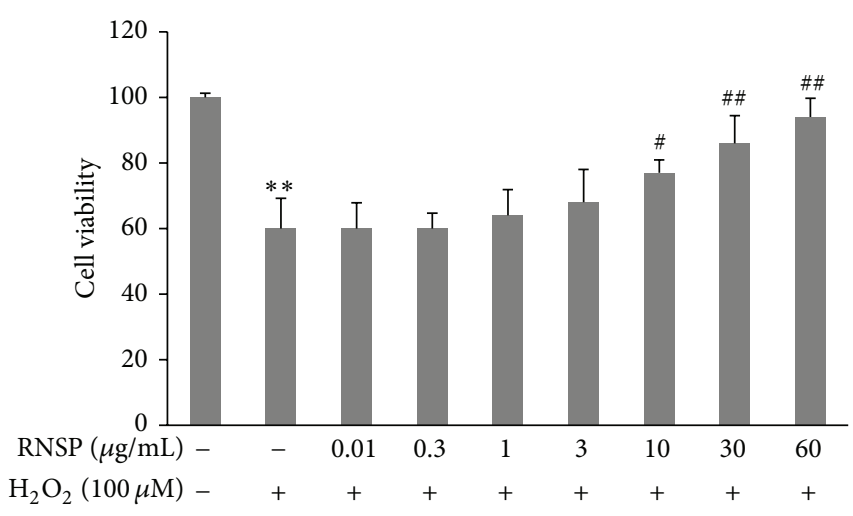

(c)

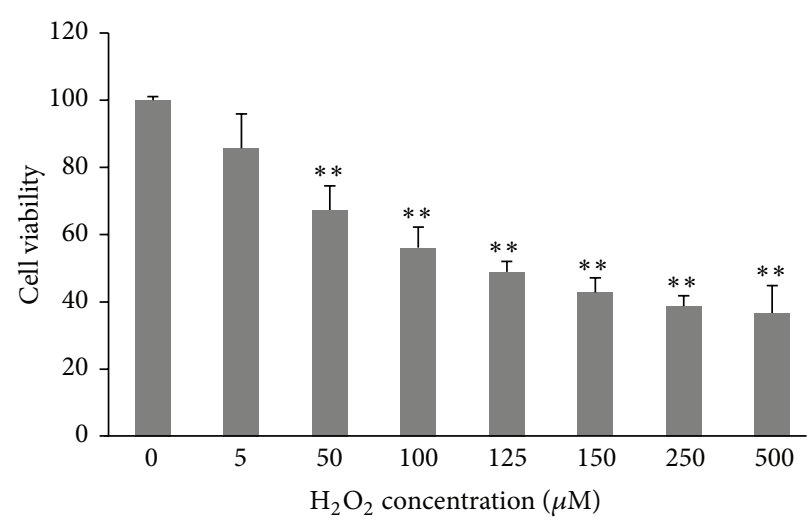

(b)
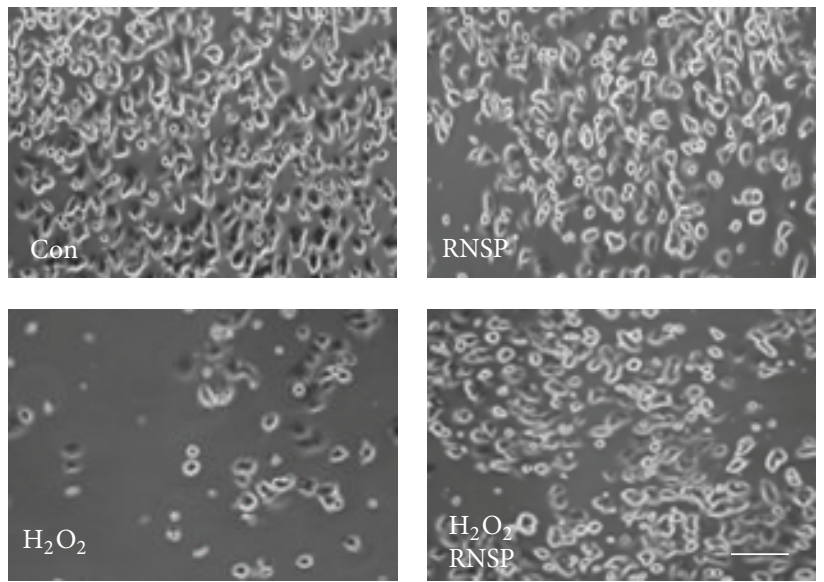

(d)

Figure 1: The effects of RNSP on $\mathrm{H}_{2} \mathrm{O}_{2}$-induced toxicity in SH-SY5Y cells. (a) The cell viability of SH-SY5Y cells after treatment with RNSP for 5 days. (b) The cell viability of SH-SY5Y cells after 24 h of exposure to $\mathrm{H}_{2} \mathrm{O}_{2}$. (c) The effect of RNSP on $\mathrm{H}_{2} \mathrm{O}_{2}$-induced toxicity in SH-SY5Y cells. Pretreatment was performed with RNSP (5 days) before exposure to $\mathrm{H}_{2} \mathrm{O}_{2}(100 \mu \mathrm{M}, 24 \mathrm{~h})$. Each column and bar represent the mean \pm $\operatorname{SEM}(n=4$ each $)$. Asterisks indicate a statistically significant difference from the value in untreated cells $\left({ }^{*} p<0.05,{ }^{* *} p<0.01\right)$. Pound signs indicate a statistically significant difference from the value in $\mathrm{H}_{2} \mathrm{O}_{2}$-exposed cells without pretreatment with RNSP $\left({ }^{\#} p<0.05\right.$, $\left.{ }^{\# \#} p<0.01\right)$. (d) The morphological changes of SH-SY5Y cells with or without pretreatment with RNSP $\left(60 \mu \mathrm{g} / \mathrm{mL}, 5\right.$ days) after exposure to $\mathrm{H}_{2} \mathrm{O}_{2}$ for $24 \mathrm{~h}$. Scale bar $=20 \mu \mathrm{m}$.

also reduced by $\mathrm{H}_{2} \mathrm{O}_{2}$ in a dose-dependent manner (data not shown). It is noted that the neuritis and shrinkage of cells were attenuated by pretreatment with RNSP (Figure 1(d)). To determine the effects of the soluble components of RNSP, we further examined the effects of water extracts of RNSP on $\mathrm{H}_{2} \mathrm{O}_{2}$-induced toxicity in SH-SY5Y cells in comparison to the methanol extracts of RNSP. As shown in Figures 2(a) and 2(b), pretreatment with the RNSP water extracts for 5 days reduced the $\mathrm{H}_{2} \mathrm{O}_{2}$-induced toxicity in SH-SY5Y cells in a dose-dependent manner. No significant difference was detected between the water and methanol extracts (Figures 2(a) and 2(b)). To further address the protective effects of RNSP over short time periods, pretreatment with methanol extracts of RNSP for $2 \mathrm{~h}$ as well as twice for $2 \mathrm{~h}$ with a $2 \mathrm{~h}$ interval $(2-2 \mathrm{~h})$ was performed in SH-SY5Y cells before exposure to $\mathrm{H}_{2} \mathrm{O}_{2}(24 \mathrm{~h})$. As shown in Figures 2(c) and 2(d), pretreatment with RNSP for both $2 \mathrm{~h}$ and $2-2 \mathrm{~h}$ significantly inhibited the $\mathrm{H}_{2} \mathrm{O}_{2}$-induced cytotoxicity in SH-SY5Y cells in a dose-dependent manner, and no significant difference was detected between the two treatment schedules in the effects on the $\mathrm{H}_{2} \mathrm{O}_{2}$-induced toxicity in cells. Taken together, these observations strongly demonstrate that pretreatment with RNSP protects SH-SY5Y cells from $\mathrm{H}_{2} \mathrm{O}_{2}$-induced cytotoxicity. Pretreatment with methanol extracts of RNSP $(60 \mu \mathrm{g} / \mathrm{mL})$ for $2 \mathrm{~h}$ was set up in the subsequent experiments.

3.3. The Effects of RNSP on $\mathrm{H}_{2} \mathrm{O}_{2}$-Induced DNA Damage in SH-SY5Y Cells. Oxidative stress is an important inducer of neurotoxicity in $\mathrm{AD}$ patients [37], causing damage to cardinal cellular components, including the DNA, and initiating subsequent cell death [38]. Following our previous experiments, we used two approaches to address the effects of RNSP on $\mathrm{H}_{2} \mathrm{O}_{2}$-induced DNA damage in SH-SY5Y cells: one approach was the use of a MitoSOX Red probe, as a marker for mitochondria-derived ROS generation [33], and the other was immunofluorescence imaging for a biomarker of oxidation-damaged DNA marker, 8-oxo-dG [39]. In comparison to the untreated cells, the expression of MitoSOX 


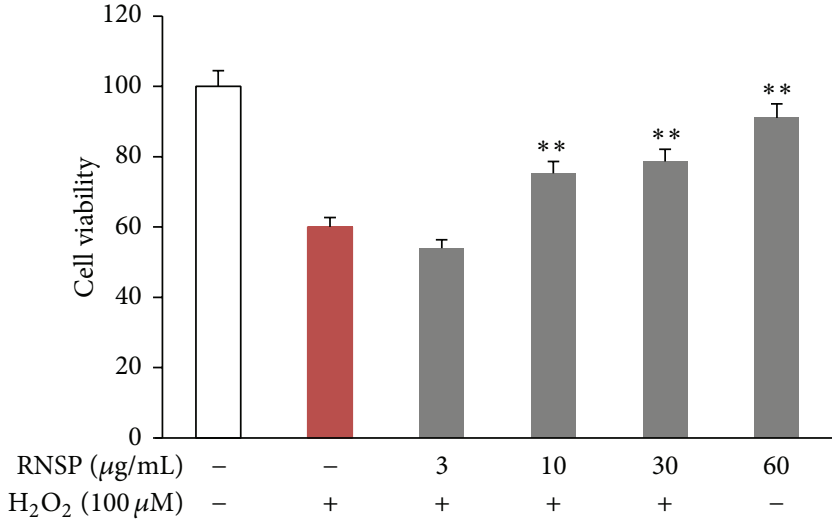

(a)

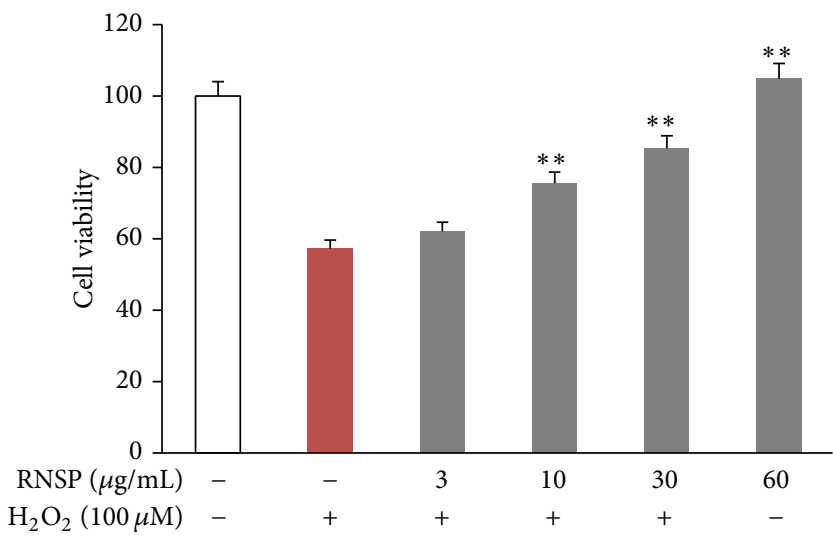

(c)

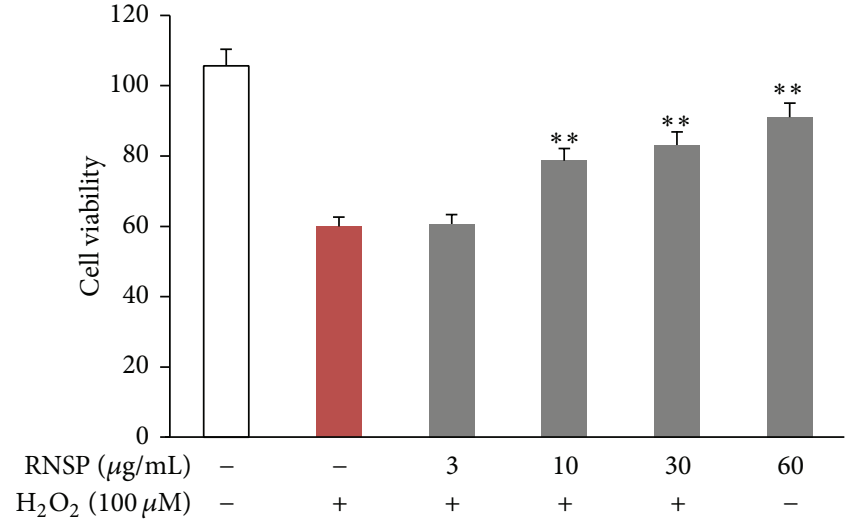

(b)

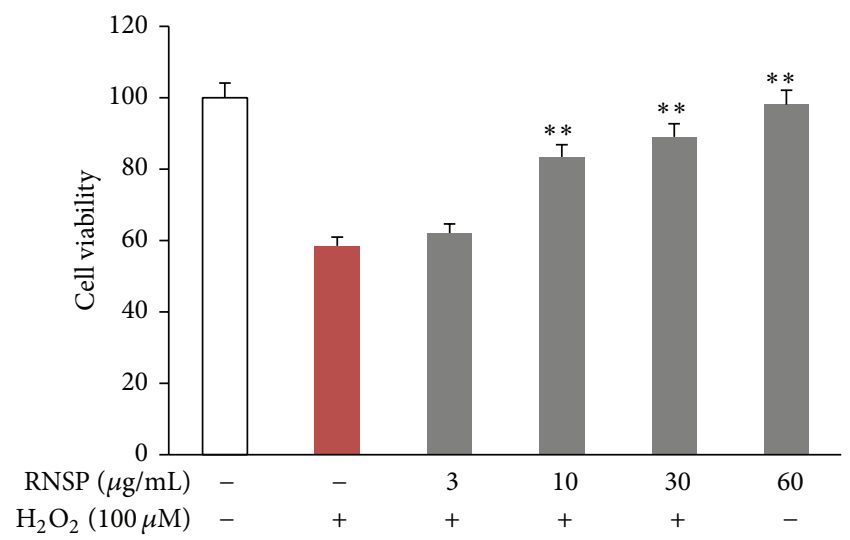

(d)

FIGURE 2: The effects of RNSP in different solvents and times on $\mathrm{H}_{2} \mathrm{O}_{2}$-induced toxicity in SH-SY5Y cells. Pretreatment with water extracts (a) and methanol extracts (b) of RNSP for 5 days. Each column and bar represent the mean \pm SEM $(n=4$ each). Asterisks indicate a statistically significant difference from the value in the $\mathrm{H}_{2} \mathrm{O}_{2}$-exposed cells without RNSP $\left({ }^{* *} p<0.01\right)$. The effect of pretreatment with methanol extracts of RNSP for $2 \mathrm{~h} \mathrm{(c)} \mathrm{and} 2 \mathrm{~h}$ two times in a $2 \mathrm{~h}$ interval (2-2 h) (d) on $\mathrm{H}_{2} \mathrm{O}_{2}$-exposed SH-SY5Y cells. Each column and bar represent the mean \pm SEM $\left(n=4\right.$ each). Asterisks indicate a statistically significant difference from the value in the $\mathrm{H}_{2} \mathrm{O}_{2}$-incubated cells without RNSP $\left.{ }^{* *} p<0.01\right)$.

Red signals was significantly increased in SH-SY5Y cells after exposure to $\mathrm{H}_{2} \mathrm{O}_{2}$ for $1 \mathrm{~h}$, suggesting that the mitochondria are the early origin of ROS generation during oxidative stress. Pretreatment with RNSP significantly inhibited the $\mathrm{H}_{2} \mathrm{O}_{2}$ induced mitochondria-derived ROS generation in SH-SY5Y cells (Figure 3(a)), thus confirming the antioxidant properties of RNSP. Immunofluorescence imaging showed a significant inverse relationship between Hoechst and 8-oxo-dG after exposure of SH-SY5Y cells to $\mathrm{H}_{2} \mathrm{O}_{2}$ for $4 \mathrm{~h}$ (Figure 3(c)), and the mean fluorescent intensity of 8-oxo-dG was found to significantly increase in comparison to that in the cells that were not exposed to $\mathrm{H}_{2} \mathrm{O}_{2}$ (7.22 versus $2.75,{ }^{* * *} p<$ $0.001)$. It is noted that pretreatment with the RNSP methanol extracts for $2 \mathrm{~h}$ significantly reduced the immunofluorescence intensity of 8-oxo-dG in the $\mathrm{H}_{2} \mathrm{O}_{2}$-exposed SH-SY5Y cells (3.60 versus 7.22, \#\# $p<0.001$, Figures $3(\mathrm{c})$ and 3(d)). These observations demonstrate that RNSP could attenuate oxidative stress-induced DNA damage in neuronal cells.
3.4. The Effects of RNSP on the $\mathrm{H}_{2} \mathrm{O}_{2}$-Induced Downregulation of REST in SH-SY5Y Cells. Recently, the neuroprotective role of repressor element-1 silencing transcription factor (REST) has been shown in the repression of ROS production and oxidative stress [40]. We thus examined the effects of RNSP on $\mathrm{H}_{2} \mathrm{O}_{2}$-induced REST expression in SH-SY5Y cells. A realtime quantitative RT-PCR analysis showed that the REST expression was significantly reduced after the exposure of SHSY5Y cells to $100 \mu \mathrm{M}$ of $\mathrm{H}_{2} \mathrm{O}_{2}$ (reduced to $85 \%$ at $1 \mathrm{~h}$ and $68 \%$ at $2 \mathrm{~h}$ in comparison to the nonexposed cells, Figure 3(b)), indicating that the downregulation of REST expression is preceded to $\mathrm{H}_{2} \mathrm{O}_{2}$-induced oxidative DNA damage. To our surprise, pretreatment with methanol extracts of RNSP for $2 \mathrm{~h}$ significantly reversed the $\mathrm{H}_{2} \mathrm{O}_{2}$-reduced the expression of REST from $1 \mathrm{~h}$ (reversed $87.8 \%$ at $1 \mathrm{~h}$ and $87.8 \%$ at $2 \mathrm{~h}$ in comparison with $\mathrm{H}_{2} \mathrm{O}_{2}$-exposed cells, Figure $3(\mathrm{~b})$ ). This observation suggests that the reversion of RNSP in $\mathrm{H}_{2} \mathrm{O}_{2}$ reduced REST expression may be involved in preventing oxidative DNA damage in SH-SY5Y cells. 

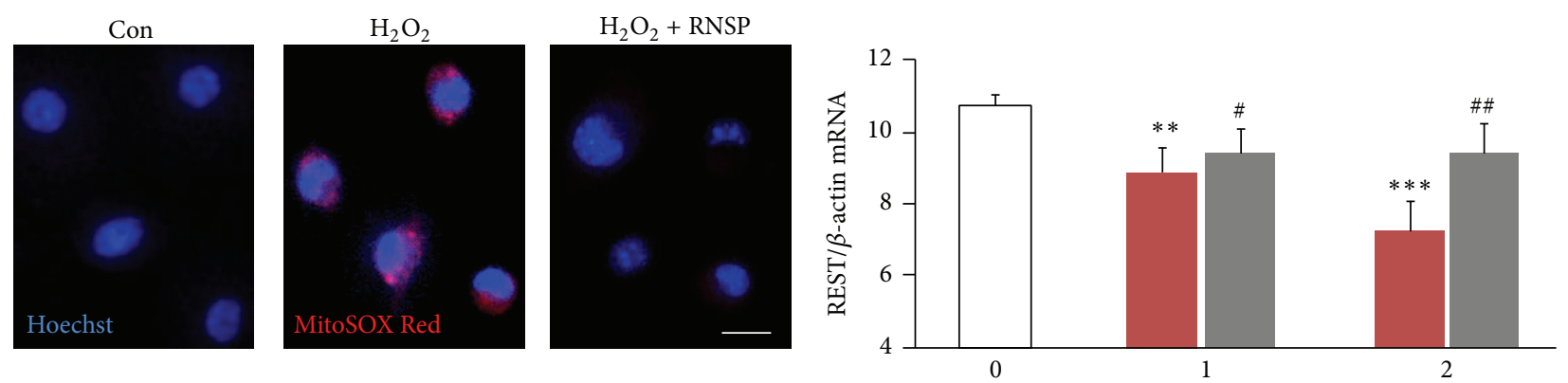

(h)

(a)
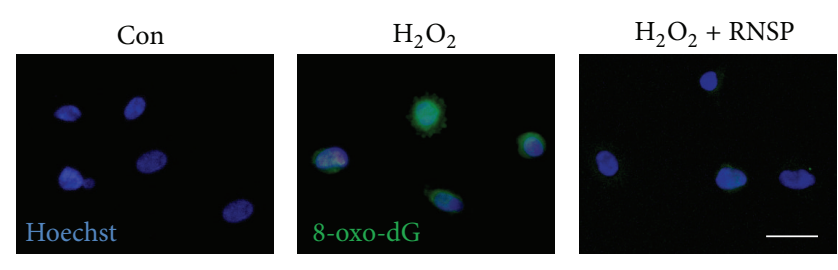

(c)

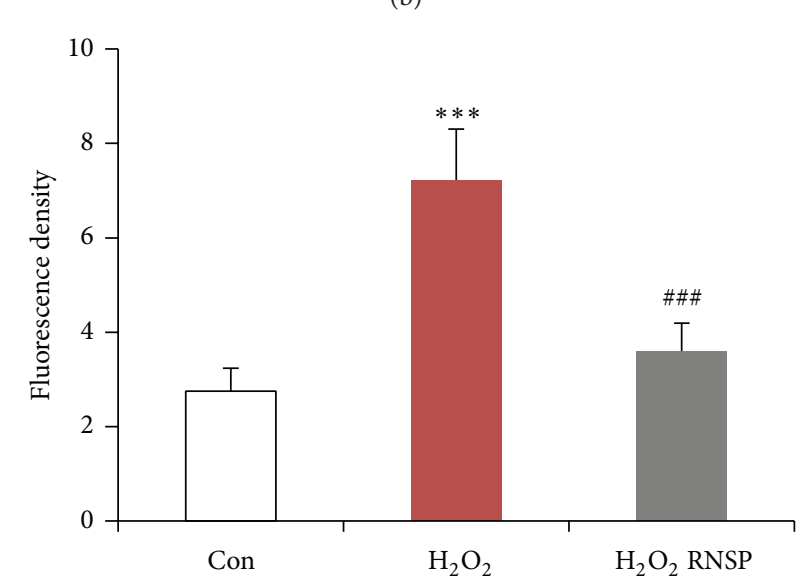

(b)

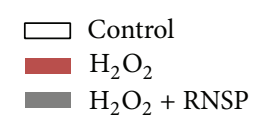

(d)

FIGURE 3: The effects of RNSP on $\mathrm{H}_{2} \mathrm{O}_{2}$-induced DNA damage in SH-SY5Y cells. (a) Fluorescent images of MitoSOX Red signals in the $\mathrm{H}_{2} \mathrm{O}_{2}$-incubated cells $(100 \mu \mathrm{M}, 1 \mathrm{~h})$ with or without RNSP $(60 \mu \mathrm{g} / \mathrm{mL}, 2 \mathrm{~h})$. Scale bar $=10 \mu \mathrm{m}$. (b) REST expression, as analyzed by real-time quantitative RT-PCR, in the $\mathrm{H}_{2} \mathrm{O}_{2}$-exposed cells $(100 \mu \mathrm{M}, 1 \mathrm{~h}, 2 \mathrm{~h})$, with or without RNSP $(60 \mu \mathrm{g} / \mathrm{mL}, 2 \mathrm{~h})$. Each column and bar represent the mean $\pm \operatorname{SEM}(n=4$ each $)$. Asterisks indicate a statistically significant difference from the value in the untreated cells $\left({ }^{* * *} p<0.01\right.$, $\left.{ }^{* *} p<0.001\right)$. Pound signs indicate a statistically significant difference from the value in the $\mathrm{H}_{2} \mathrm{O}_{2}$-incubated cells without RNSP $\left({ }^{\#} p<0.05\right.$, \#\# $p<0.01$ ). (c) Immunofluorescent CLMS images of 8-oxo-dG (green) with Hoechst-stained nuclei (blue) in the $\mathrm{H}_{2} \mathrm{O}_{2}$-exposed cells (100 $\mu \mathrm{M}$ $4 \mathrm{~h}$ ), with or without RNSP $(60 \mu \mathrm{g} / \mathrm{mL}, 2 \mathrm{~h})$. Scale bar $=10 \mu \mathrm{m}$. (d) The quantitative analyses of 8 -oxo-dG immunofluorescence signal intensity in (c). Each column and bar represent the mean \pm SEM $(n=4$ each). Asterisks indicate a statistically significant difference from the value in the untreated cells $\left({ }^{* * *} p<0.001\right)$. Pound signs indicate a statistically significant difference from the value in the $\mathrm{H}_{2} \mathrm{O}_{2}$-exposed cells without RNSP $\left({ }^{\# \#} p<0.001\right)$.

3.5. The Effects of RNSP on $\mathrm{H}_{2} \mathrm{O}_{2}$-Mediated MAPK Activation in SH-SY5Y Cells. We finally examined the effects of RNSP on $\mathrm{H}_{2} \mathrm{O}_{2}$-induced p38, ERK1/2, and JNK phosphorylation in SH-SY5Y cells, because they are known to be cell death factors which are mediated by oxidative stress $[12,13]$. In comparison to the cells that were not exposed to $\mathrm{H}_{2} \mathrm{O}_{2}$, the mean level of phosphorylated p38 MAPK was significantly increased in SH-SY5Y cells from 30 min to 60 min after exposure to $\mathrm{H}_{2} \mathrm{O}_{2}$ $(100 \mu \mathrm{M})$ (Figures 4(a) and 4(b)). Along the same lines, the phosphorylated ERK 1/2 MAPK was significantly increased from 60 min after exposure to $\mathrm{H}_{2} \mathrm{O}_{2}$ (Figures 4(c) and 4(d)). However, the mean level of phosphorylated JNK was not significantly increased in SH-SY5Y cells after exposure to $\mathrm{H}_{2} \mathrm{O}_{2}$ (data not shown). Interestingly, pretreatment with the methanol extracts of RNSP for $2 \mathrm{~h}$ significantly inhibited the $\mathrm{H}_{2} \mathrm{O}_{2}$-induced phosphorylation of both p38 and ERK 1/2 MAPK from 60 min after incubation with $\mathrm{H}_{2} \mathrm{O}_{2}$ in SH-SY5Y cells (Figures 4(a)-4(d)). However, pretreatment with RNSP for $2 \mathrm{~h}$ did not significantly inhibit the phosphorylation of JNK in the SH-SY5Y cells. These observations demonstrate that RNSP could inhibit oxidative stress-induced MAPK activation in SH-SY5Y cells.

\section{Discussion}

The major findings of the present study are that RNSP protects SH-SY5Y cells from $\mathrm{H}_{2} \mathrm{O}_{2}$-induced neuronal cytotoxicity by reducing the oxidative stress-induced DNA damage and activation of MAPK (summarized in Figure 5). It 


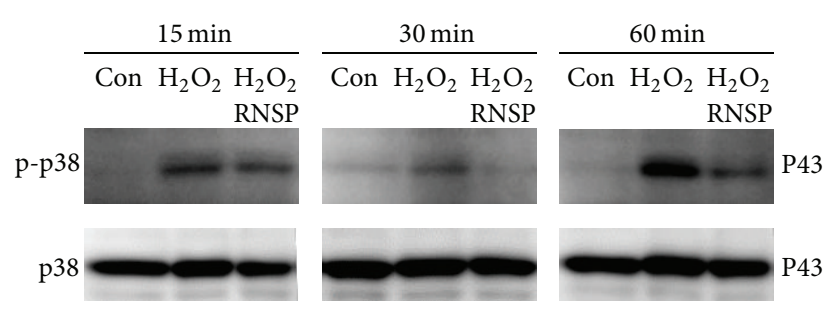

(a)

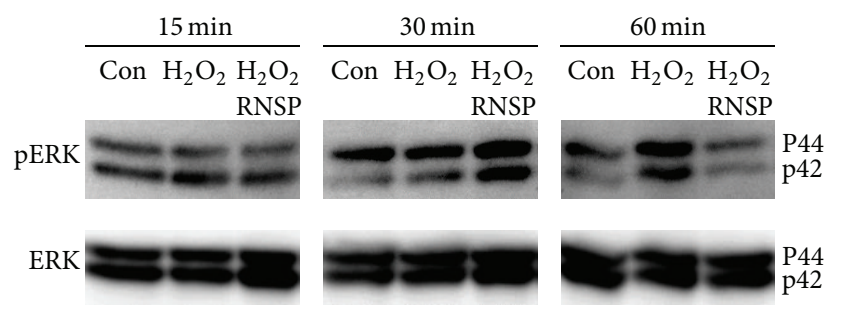

(c)

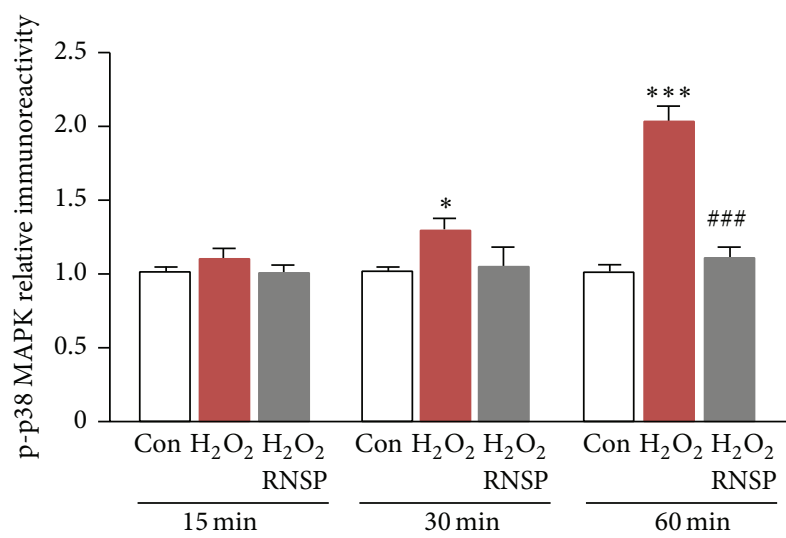

(b)

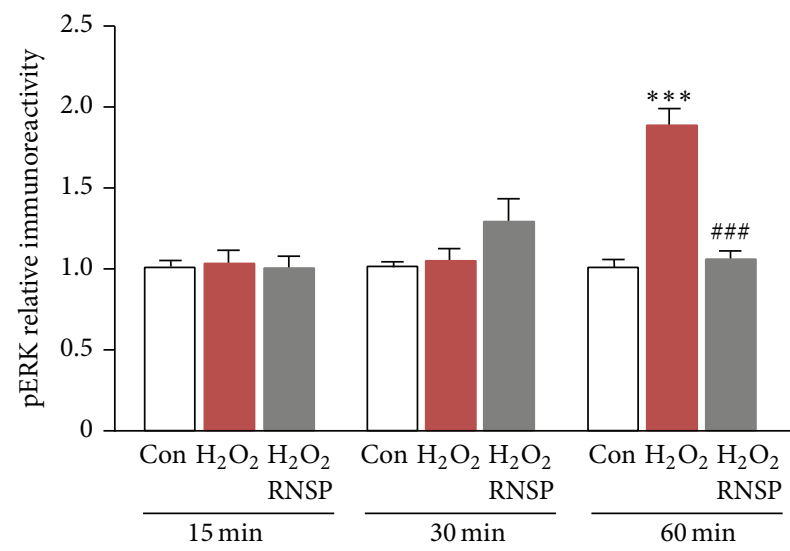

(d)

FIgURE 4: The effects of RNSP on $\mathrm{H}_{2} \mathrm{O}_{2}$-medicated MAPKs activation in SH-SY5Y cells. (a) The phosphorylation of $\mathrm{p} 38$ in $\mathrm{H}_{2} \mathrm{O}_{2}$-exposed cells with or without RNSP $(60 \mu \mathrm{g} / \mathrm{mL}, 2 \mathrm{~h})$. (b) The quantitative analyses of the immunoblotting from (a). Each column and bar represent the mean $\pm \operatorname{SEM}\left(n=4\right.$, each). An asterisk indicates a statistically significant difference from the value in the untreated cells $\left({ }^{*} p<0.05\right.$, ${ }^{* * *} p<0.001$ ). Pound signs indicate a statistically significant difference from the value in $\mathrm{H}_{2} \mathrm{O}_{2}$-exposed cells without RNSP (\#\#\# $p<0.001$ ). (c) The phosphorylation of pERK1/2 in $\mathrm{H}_{2} \mathrm{O}_{2}$-exposed cells with or without RNSP $(60 \mu \mathrm{g} / \mathrm{mL}, 2 \mathrm{~h})$. (d) The quantitative analyses of the immunoblotting in (c). Each column and bar represent the mean \pm SEM $(n=4$ each). Asterisks indicate a statistically significant difference from the value in untreated cells $\left({ }^{* * *} p<0.001\right)$. Pound signs indicate a statistically significant difference from the value in the $\mathrm{H}_{2} \mathrm{O}_{2}$-exposed cells without RNSP $\left({ }^{\# \#} p<0.001\right)$.

is known that oxidative stress resulting from the overproduction of ROS causes damage to the cellular components, including DNA, resulting in subsequent cell death [5]. $\mathrm{H}_{2} \mathrm{O}_{2}$ is one of the most important ROS generated through oxidative stress $[29,30]$. In the present study, the mean fluorescent intensity of 8-oxo-dG, a biomarker for oxidative stressdamaged DNA [41], was found to be significantly increased, mainly in the nuclei of SH-SY5Y cells from $4 \mathrm{~h}$ after exposure to $\mathrm{H}_{2} \mathrm{O}_{2}$. However, the expression of MitoSOX Red probe, a marker for mitochondria-derived ROS generation in the SH-SY5Y cells, increased from $1 \mathrm{~h}$ after exposure to $\mathrm{H}_{2} \mathrm{O}_{2}$, thus indicating mitochondrial damage to be the early origin of ROS generation before the nuclear DNA damage that is caused by oxidative stress. It is noted that both the long (5 days) and the short $(2 \mathrm{~h})$ pretreatments with RNSP could significantly inhibit the $\mathrm{H}_{2} \mathrm{O}_{2}$-induced mitochondrial ROS generation and nuclear DNA damage (Figures 3(a) and 3(b)) and the subsequent cell death in SH-SY5Y cells (Figures 1 and
2). This is the first evidence support the attenuation of stressinduced DNA damage in neuronal cells by RNSP.

Recent research has shown that REST is related to the reduction of oxidative damage. This was demonstrated by increased levels of ROS as well as oxidative DNA damage in response to REST knockdown. The overexpression of REST (up to 20-fold) can reduce $\mathrm{H}_{2} \mathrm{O}_{2}$-induced neuronal cell death [40]. In the present study, the expression of REST was significantly decreased as little as $1 \mathrm{~h}$ after cells were exposed to $\mathrm{H}_{2} \mathrm{O}_{2}(100 \mu \mathrm{M})$, and the time-dependent decrease of REST expression was positively correlated with subsequent DNA damage. These results agree with the hypothesis that REST knockdown increases oxidative DNA damage [40]. Surprisingly, pretreatment with RNSP for $2 \mathrm{~h}$ significantly reversed the $\mathrm{H}_{2} \mathrm{O}_{2}$-induced decrease of REST expression from $1 \mathrm{~h}$ (Figure $3(\mathrm{a})$ ), inducing a parallel protective effect against subsequent oxidative DNA damage in SH-SY5Y cells (Figures 3(a) and 3(b)). Since REST is a protective factor 


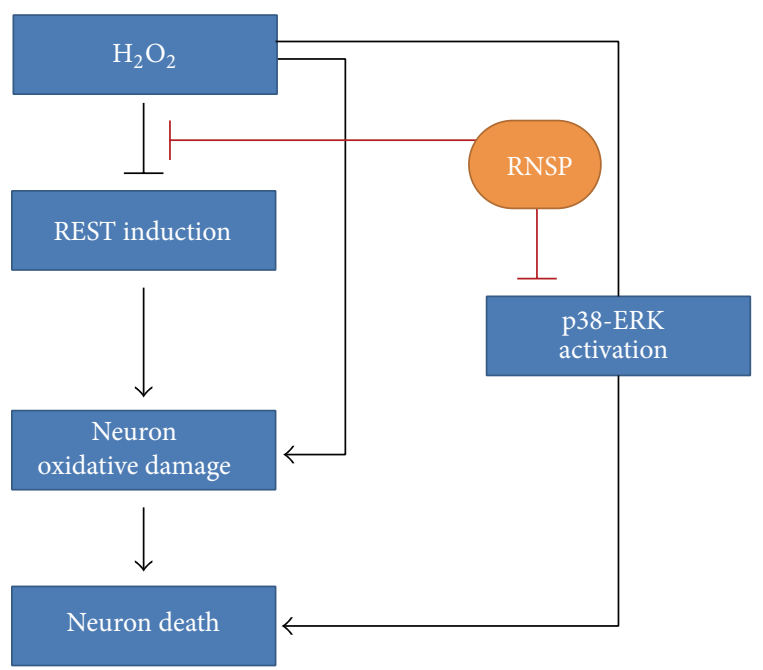

FIGURE 5: A schematic representation of the effects and the principle molecular mechanisms of RNSP on the protection from oxidative stress-induced neuronal death via the antioxidant properties and inhibition of MAPK activation.

in the ageing brain, which is in a state of decline from the early stages of $\mathrm{AD}[40]$, and because we have recently found that RNSP taken orally for 16 weeks can significantly improve cognitive function in the early stages of $\mathrm{AD}$ [18], the regulation of the $\mathrm{H}_{2} \mathrm{O}_{2}$-mediated REST/oxidative stress may be one of the principle molecular mechanisms behind the protective effects of RNSP that are observed in neuronal cells.

Oxidative stress is known to be one of the major stimulators of the MAPK cascade. The overproduction of ROS during oxidative stress acts as a second messenger in signal transduction cascades leading to MAPK activation, because the intracellular redox state of the cells regulates the cellular signaling pathways $[10,11]$. In the present study, p38 and ERK 1/2 MAPKs were significantly activated in SH-SY5Y cells after exposure to $\mathrm{H}_{2} \mathrm{O}_{2}(100 \mu \mathrm{M})$. This agrees with the hypothesis that ERK and $\mathrm{p} 38$ proteins are rapidly activated by $\mathrm{H}_{2} \mathrm{O}_{2}$ in PC12 cells $[41,42]$. Pretreatment with RNSP for $2 \mathrm{~h}$ significantly reduced the $\mathrm{H}_{2} \mathrm{O}_{2}$-induced phosphorylation of both p38 and ERK1/2, thus indicating that the reduction of the oxidative stress-mediated activation of p38 and ERK 1/2 may be another important molecular mechanism underlying the protective effects of RNSP on neuronal cells, because both p38 and ERK 1/2 MAPK are cell death factors which are mediated by oxidative stress $[12,13]$.

RNSP is composed of more than seventy components, including saffron and Glycyrrhiza uralensis [16, 17], and the beneficial effects of RNSP components have been paid attention [25]. Previous studies have shown that saffron, one of the components of RNSP, inhibits the TNF $\alpha$-induced cell death of PC12 cells [22] and protects neurons from 6hydroxydopamine hydrobromide-induced neurotoxic activity [23], through antioxidant properties of saffron [24-26]. Our previous studies have found improvements of the cognitive functions in mild-to-moderate $\mathrm{AD}$ patients living at high altitude and increases in learning and memory in a mouse model of AD (Tg2576) [17-19]; the present observations have demonstrated the direct roles of RNSP in inhibiting oxidative stress-induced DNA damage and in the activation of MAPKs in neuronal cells, further confirming the benefits of RNSP in the prevention and clinical management of AD $[7,15]$. Since oxidative stress is a potential contributor to the pathogenesis of $\mathrm{AD}[4,7,8]$ and since the levels of phosphorylated MAPKs are increased in the postmortem brains of $\mathrm{AD}$ patients [1416], the antioxidants effects of RNSP can be expected to delay the development of $\mathrm{AD}$.

\section{Conclusion}

RNSP was able to protect oxidative stress-induced neuronal damage via antioxidant properties and the inhibition of MAPK activation (schematic represented in Figure 5). These findings therefore provide the principle molecular mechanisms of the clinical effects of RNSP and support its use as therapeutic agent for the prevention and clinical management of $\mathrm{AD}$.

\section{Conflict of Interests}

The authors declare they have no conflict of interests.

\section{Authors' Contribution}

Aiqin Zhu and Zhou Wu contributed equally to this work.

\section{Acknowledgments}

This work was supported partly by Key Grant for Returnees on Science and Technology from the Ministry of Personnel, China, to Aiqin Zhu (Ministry of Personnel 2014414) and Grants-in-Aid for Scientific Research to Zhou Wu (24592802).

\section{References}

[1] G. K. Vincent and V. A. Velkoff, The Next Four Decades: The Older Population in the United States: 2010 to 2050, edited by United States Census Bureau, United States Department of Commerce, Washington, DC, USA, 2010.

[2] L. Y. Al-Ayadhi, "Oxidative stress and neurodegenerative disease," Neurosciences, vol. 9, no. 1, pp. 19-23, 2004.

[3] N. H. Zawia, D. K. Lahiri, and F. Cardozo-Pelaez, "Epigenetics, oxidative stress, and Alzheimer disease," Free Radical Biology and Medicine, vol. 46, no. 9, pp. 1241-1249, 2009.

[4] E. G. McGeer and P. L. McGeer, "Clinically tested drugs for Alzheimer's disease," Expert Opinion on Investigational Drugs, vol. 12, no. 7, pp. 1143-1151, 2003.

[5] H. U. Simon, A. Haj-Yehia, and F. Levi-Schaffer, "Role of reactive oxygen species (ROS) in apoptosis induction," Apoptosis, vol. 5, no. 5, pp. 415-418, 2000.

[6] O. I. Aruoma, H. Kaur, and B. Halliwell, "Oxygen free radicals and human diseases," Journal of the Royal Society of Health, vol. 111, no. 5, pp. 172-177, 1991. 
[7] K. Leuner, J. Pantel, C. Frey et al., "Enhanced apoptosis, oxidative stress and mitochondrial dysfunction in lymphocytes as potential biomarkers for Alzheimer's disease," Journal of Neural Transmission, Supplementa, no. 72, pp. 207-215, 2007.

[8] E. B. Turunc, Y. Uyanikgil, L. Kanit, E. Koylu, and A. Yalcin, "Nicotinamide treatment reduces the levels of oxidative stress, apoptosis, and PARP-1 activity in A $\beta(1-42)$-induced rat model of Alzheimer's disease," Free Radical Research, vol. 48, no. 2, pp. 146-158, 2014.

[9] M. Manczak, P. Mao, M. J. Calkins et al., "Mitochondriatargeted antioxidants protect against amyloid- $\beta$ toxicity in Alzheimer's disease neurons," Journal of Alzheimer's Disease, vol. 20, no. 2, pp. S609-S631, 2010.

[10] C. T. Chu, D. J. Levinthal, S. M. Kulich, E. M. Chalovich, and D. B. DeFranco, "Oxidative neuronal injury: the dark side of ERK1/2," European Journal of Biochemistry, vol. 271, no. 11, pp. 2060-2066, 2004.

[11] K. Kühn, A. R. Shikhman, and M. Lotz, "Role of nitric oxide, reactive oxygen species, and p38 MAP kinase in the regulation of human chondrocyte apoptosis," Journal of Cellular Physiology, vol. 197, no. 3, pp. 379-387, 2003.

[12] T. Wada and J. M. Penninger, "Mitogen-activated protein kinases in apoptosis regulation," Oncogene, vol. 23, no. 16, pp. 2838-2849, 2004.

[13] H. Nakano, S. Ikenaga, T. Aizu et al., "Human metallothionein gene expression is upregulated by $\beta$-thujaplicin: possible involvement of protein kinase C and reactive oxygen species," Biological and Pharmaceutical Bulletin, vol. 29, no. 1, pp. 55-59, 2006.

[14] J. J. Haddad, "Mitogen-activated protein kinases and the evolution of Alzheimer's: a revolutionary neurogenetic axis for therapeutic intervention?" Progress in Neurobiology, vol. 73, no. 5, pp. 359-377, 2004.

[15] L. Munoz, H. R. Ranaivo, S. M. Roy et al., "A novel p38 alpha MAPK inhibitor suppresses brain proinflammatory cytokine up-regulation and attenuates synaptic dysfunction and behavioral deficits in an Alzheimer's disease mouse model," Journal of Neuroinflammation, vol. 4, article 21, 2007.

[16] X. Zhu, R. J. Castellani, A. Takeda et al., "Differential activation of neuronal ERK, JNK/SAPK and p38 in Alzheimer disease: the 'two hit' hypothesis,' Mechanisms of Ageing and Development, vol. 123, no. 1, pp. 39-46, 2001.

[17] A.-Q. Zhu, Y.-D. Chu, Q.-X. Li, and C. L. Masters, “Tibetmedicine effects on $\beta$-amyloid pathology in a transgenic mouse model of Alzheimer's disease," Chinese Pharmacological Bulletin, vol. 25, no. 6, pp. 720-724, 2009.

[18] A. Q. Zhu, C. L. Masters, and Q. X. Li, "Tibet-medicine Ratanasampil modulates amyloid precursor protein cleavage and C-terminal fragments (CTFS) in Tg2576 transgenic mice brain of Alzheimer's disease," Chinese Journal of Geriatrics, vol. 11, pp. 950-954, 2009.

[19] A. Q. Zhu, A. Q. Xi, G. F. Li et al., "Ratanasampil (Tibetan medicine, RNSP) reduces $\beta$-amyloid protein $(\mathrm{A} \beta)$ and proinflammatory factor levels and improves cognitive functions in mild-to-moderate Alzheimer's disease (AD) patients living at high altitude," Journal of Behavioral and Brain Science, vol. 2, pp. 82-91, 2012.

[20] E. J. An and Y. R. Suo, "Pharmacology research on Tibetan medicine seventy-taste-pearl-balls," Journal of Medicine \& Pharmacy of Chinese Minorities, vol. 4, pp. 33-35, 2004.
[21] S. H. L. Bayi and H. Hu, "Research advances in Tibetan medicine seventy-taste-pearl-balls," Xinjiang Journal of Traditional Chinese Medicine, vol. 5, pp. 82-83, 2005.

[22] S. Soeda, T. Ochiai, L. Paopong, H. Tanaka, Y. Shoyama, and H. Shimeno, "Crocin suppresses tumor necrosis factor- $\alpha$-induced cell death of neuronally differentiated PC-12 cells," Life Sciences, vol. 69, no. 24, pp. 2887-2898, 2001.

[23] A. S. Ahmad, M. A. Ansari, M. Ahmad et al., "Neuroprotection by crocetin in a hemi-parkinsonian rat model," Pharmacology Biochemistry and Behavior, vol. 81, no. 4, pp. 805-813, 2005.

[24] S. A. Ordoudi, C. D. Befani, N. Nenadis, G. G. Koliakos, and M. Z. Tsimidou, "Further examination of antiradical properties of crocus sativus stigmas extract rich in crocins," Journal of Agricultural and Food Chemistry, vol. 57, no. 8, pp. 3080-3086, 2009.

[25] M. A. Papandreou, C. D. Kanakis, M. G. Polissiou et al., "Inhibitory activity on amyloid- $\beta$ aggregation and antioxidant properties of Crocus sativus stigmas extract and its crocin constituents," Journal of Agricultural and Food Chemistry, vol. 54, no. 23, pp. 8762-8768, 2006.

[26] M. A. Papandreou, M. Tsachaki, S. Efthimiopoulos, P. Cordopatis, F. N. Lamari, and M. Margarity, "Memory enhancing effects of saffron in aged mice are correlated with antioxidant protection," Behavioural Brain Research, vol. 219, no. 2, pp. 197204, 2011

[27] H.-J. Chen, S.-P. Kang, I.-J. Lee, and Y.-L. Lin, "Glycyrrhetinic acid suppressed NF- $\kappa \mathrm{B}$ activation in TNF- $\alpha$-induced hepatocytes," Journal of Agricultural and Food Chemistry, vol. 62, no. 3, pp. 618-625, 2014.

[28] H. Honda, Y. Nagai, T. Matsunaga et al., "Isoliquiritigenin is a potent inhibitor of NLRP3 inflammasome activation and diet-induced adipose tissue inflammation," Journal of Leukocyte Biology, vol. 96, no. 6, pp. 1087-1100, 2014.

[29] H. J. Forman, "Use and abuse of exogenous $\mathrm{H}_{2} \mathrm{O}_{2}$ in studies of signal transduction," Free Radical Biology and Medicine, vol. 42, no. 7, pp. 926-932, 2007.

[30] Y. Li, J. Hugenholtz, T. Abee, and D. Molenaar, "Glutathione protects Lactococcus lactis against oxidative stress," Applied and Environmental Microbiology, vol. 69, no. 10, pp. 5739-5745, 2003.

[31] Z. Gao, K. Huang, and H. Xu, "Protective effects of flavonoids in the roots of Scutellaria baicalensis Georgi against hydrogen peroxide-induced oxidative stress in HS-SY5Y cells," Pharmacological Research, vol. 43, no. 2, pp. 173-178, 2001.

[32] D. Uberti, L. Piccioni, A. Colzi, D. Bravi, P. L. Canonico, and M. Memo, "Pergolide protects SH-SY5Y cells against neurodegeneration induced by $\mathrm{H}_{2} \mathrm{O}_{2}$," European Journal of Pharmacology, vol. 434, no. 1-2, pp. 17-20, 2002.

[33] Z. Wu, A. Zhu, F. Takayama et al., "Brazilian green propolis suppresses the hypoxia-induced neuroinflammatory responses by inhibiting NF- $\kappa \mathrm{B}$ activation in microglia," Oxidative Medicine and Cellular Longevity, vol. 2013, Article ID 906726, 10 pages, 2013.

[34] Z. Wu, L. Sun, S. Hashioka et al., "Differential pathways for interleukin- $1 \beta$ production activated by chromogranin $\mathrm{A}$ and amyloid $\beta$ in microglia," Neurobiology of Aging, vol. 34, no. 12, pp. 2715-2725, 2013.

[35] B. Lei, N. Adachi, and T. Arai, "The effect of hypothermia on $\mathrm{H}_{2} \mathrm{O}_{2}$ production during ischemia and reperfusion: A microdialysis study in the gerbil hippocampus," Neuroscience Letters, vol. 222, no. 2, pp. 91-94, 1997. 
[36] K. Kitagawa, M. Matsumoto, M. Hori, and T. Yanagihara, "Neuroprotective effect of apolipoprotein E against ischemia," Annals of the New York Academy of Sciences, vol. 977, pp. 468475, 2002.

[37] J. Choi, M. C. Sullards, J. A. Olzmann et al., "Oxidative damage of DJ-1 is linked to sporadic Parkinson and Alzheimer diseases," The Journal of Biological Chemistry, vol. 281, no. 16, pp. 1081610824, 2006.

[38] A. M. Gorman, A. McGowan, C. O’Neill, and T. Cotter, “Oxidative stress and apoptosis in neurodegeneration," Journal of the Neurological Sciences, vol. 139, supplement, pp. 45-52, 1996.

[39] E. W. Englander, Z. Hu, A. Sharma, H.-M. Lee, Z.-H. Wu, and G. H. Greeley, "Rat MYH, a glycosylase for repair of oxidatively damaged DNA, has brain-specific isoforms that localize to neuronal mitochondria," Journal of Neurochemistry, vol. 83, no. 6, pp. 1471-1480, 2002.

[40] T. Lu, L. Aron, J. Zullo et al., "REST and stress resistance in ageing and Alzheimer's disease," Nature, vol. 507, no. 7493, pp. 448-454, 2014.

[41] Z. Spicer and D. E. Millhorn, "Oxygen sensing in neuroendocrine cells and other cell types: pheochromocytoma (PC12) cells as an experimental model," Endocrine Pathology, vol. 14, no. 4, pp. 277-291, 2003.

[42] Y. Suzaki, M. Yoshizumi, S. Kagami et al., "Hydrogen peroxide stimulates c-Src-mediated big mitogen-activated protein kinase 1 (BMK1) and the MEF2C signaling pathway in PC12 cells. Potential role in cell survival following oxidative insults," The Journal of Biological Chemistry, vol. 277, no. 11, pp. 9614-9621, 2002. 


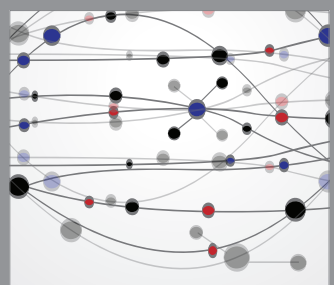

The Scientific World Journal
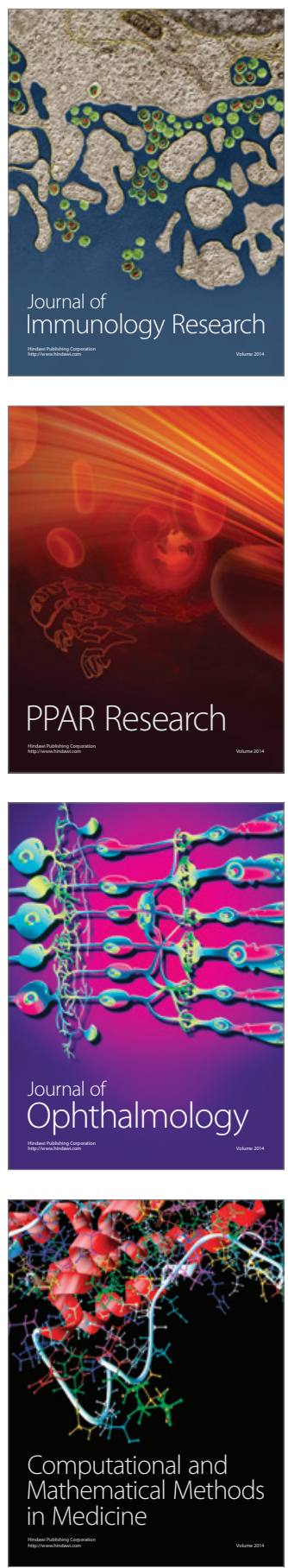

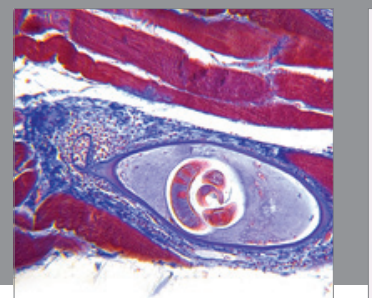

Gastroenterology

Research and Practice
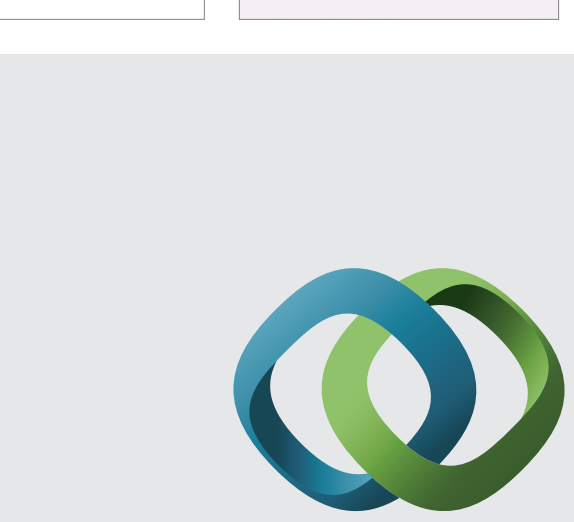

\section{Hindawi}

Submit your manuscripts at

http://www.hindawi.com
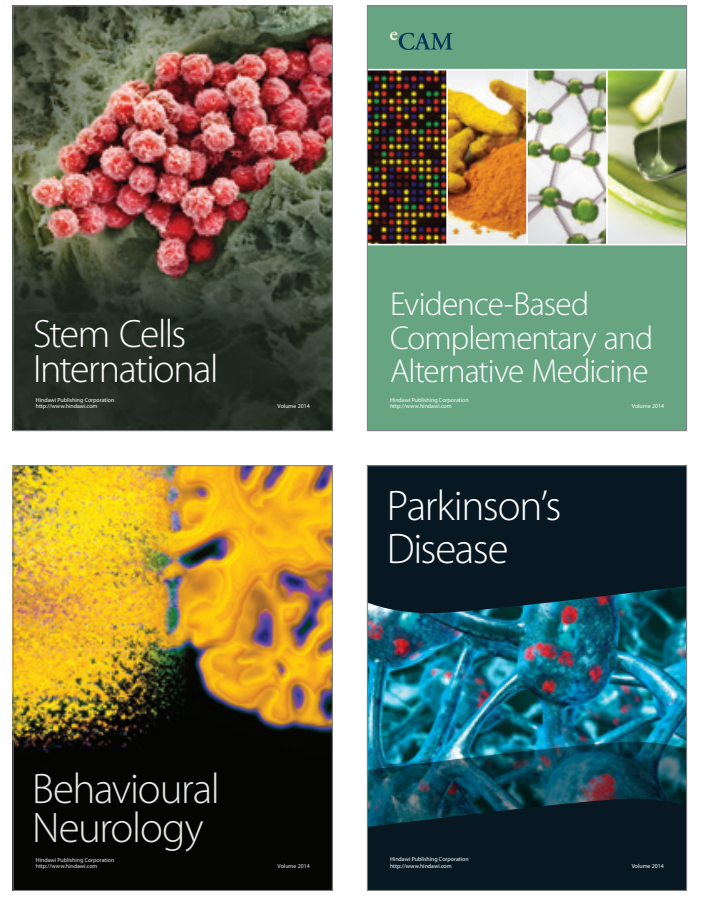
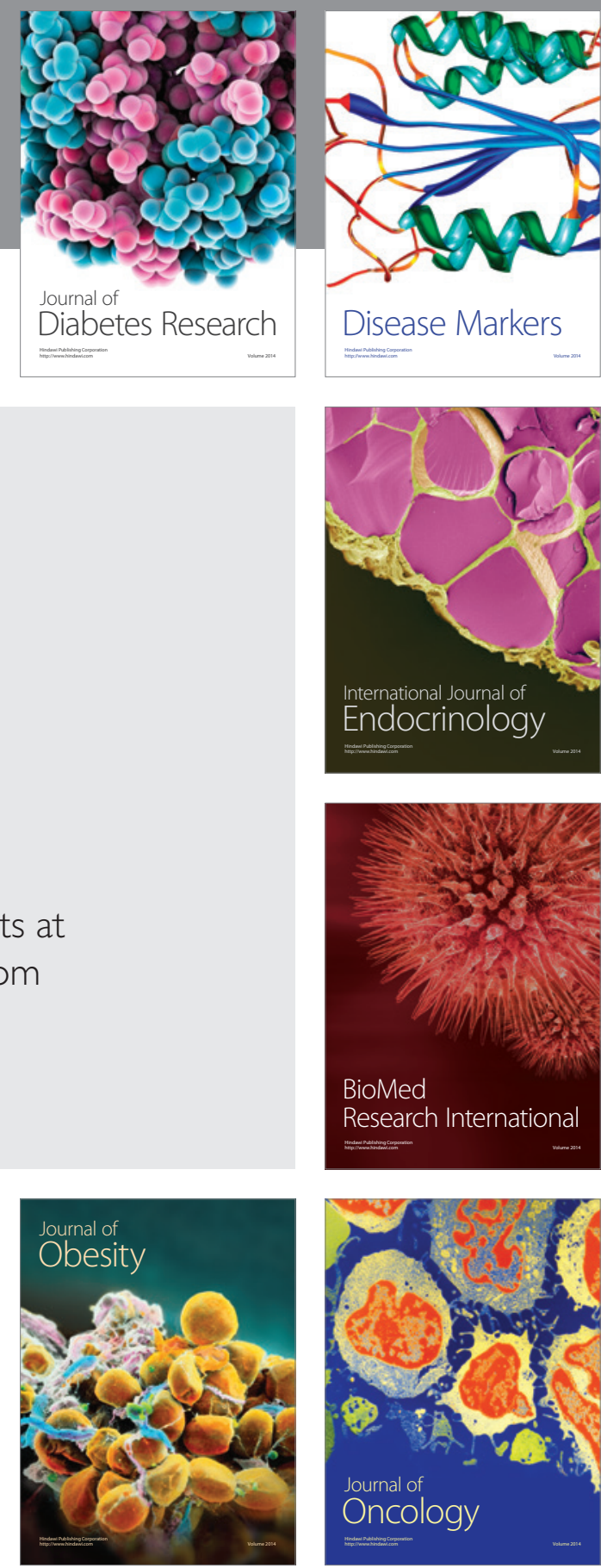

Disease Markers
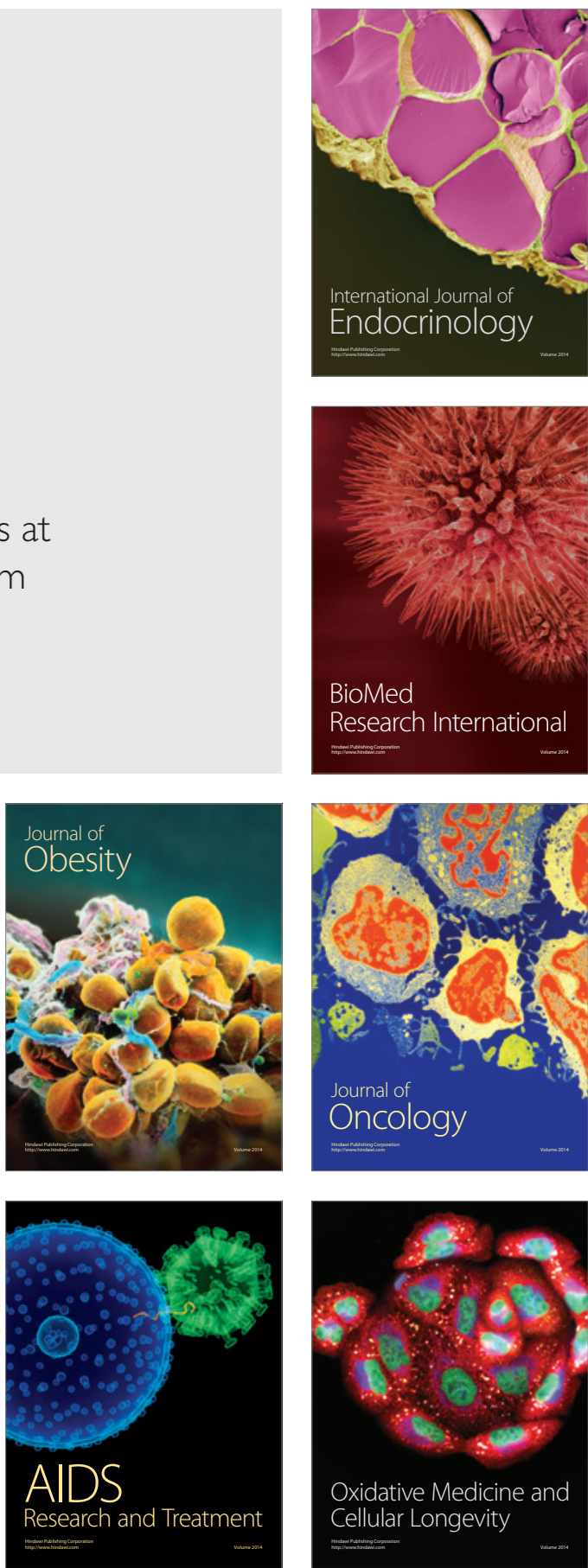